\title{
Practical Illustrated Histology
}




\section{Practical Illustrated Histology}

\section{N. A. Ratcliffe}

Reader in Zoology, Department of Zoology, University College of Swansea

Illustrations by

P. J. Llewellyn

Technical Illustrator, Department of Zoology, University College of Swansea 
Text and photographs (CN. A. Ratcliffe 1982

Line diagrams (C). J. Llewellyn 1982

Softcover reprint of the hardcover 1st edition 1982 978-0-333-32653-4

All rights reserved. No part of this publication may be reproduced or transmitted, in any form or by any means, without permission.

First published 1982 by

THE MACMILLAN PRESS LTD

London and Basingstoke

Companies and representatives throughout the world

ISBN 978-0-333-25635-0 ISBN 978-1-349-86060-9 (eBook)

DOI 10.1007/978-1-349-86060-9

The paperback edition of this book is sold subject to the condition that it shall not, by way of trade or otherwise, be lent, resold, hired out, or otherwise circulated without the publisher's prior consent in any form of binding or cover other than that in which it is published and without a similar condition including this condition being imposed on the subsequent purchaser. 


\section{Contents}

Preface vii

1 The Cell-Structure and Methods of Observation 1

2 Some Useful Hints and Recipes for the Preparation and

Examination of Stained Histological Sections $\quad 24$

3 Location of Organs in Adult and Embryo - 38

4 Epithelia $\quad 43$

$5 \quad$ Connective and Supporting Tissues $\quad 48$

6 Muscular Tissues $\quad 63$

7 Blood and Vascular System $\quad 68$

8 Respiratory System $\quad 76$

9 Integumentary System (Skin) $\quad 85$

$\begin{array}{lll}10 & \text { Lymphoid Tissues } & 90\end{array}$

11 Digestive System and Associated Glands 100

12 Urinary System 138

13 Male Reproductive System $r$

14 Female Reproductive System 158

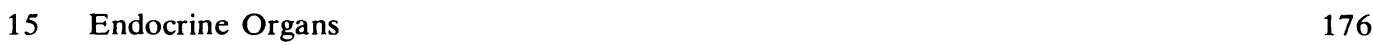

16 Nervous System 190

17 Sense Organs $\quad 205$

$\begin{array}{lr}\text { Further Reading } & 219\end{array}$

$\begin{array}{ll}\text { Index } & 221\end{array}$ 


\section{Preface}

Practical Illustrated Histology is designed to assist the student in the laboratory with the identification and understanding of histological sections. To this end, low-, medium- and high-power photomicrographs of most mammalian tissues are presented and also accurate and clearly labelled drawings together with lists of characteristic features. The micrographs are thus not covered in distractive and obscure labelling while the drawings allow some licence for clarification of indistinct features. The importance of the interrelationship of structure with function is also emphasised throughout by the listing of both tissue characteristics and functions, and by means of brief synopses, of basic physiology and morphology, at the beginning of each chapter.

This book is written primarily for students new to histology at school and college levels and, in order briefly to introduce the subject to the beginner, the first chapter contains basic information on the cell, methods of microscopy, resolution, cell morphology and ultrastructure.

Practical Illustrated Histology, however, is not aimed at replacing the more advanced theoretical texts but, with its synopses and diagrams of the main systems of the body, together with the clearly labelled drawings and summaries of characteristic features and functions, it should prove most useful not only as an introductory manual but also for both revision and reference purposes.
Additional features which underline the value of the book at the bench level are the inclusion of step-by-step practical schedules for tissue processing and staining. Detailed instructions are given for the commonly used haematoxylin and eosin technique and also for the more advanced staining methods which have been employed in the book. Advice is also provided on microtomy, the interpretation and drawing of histological sections and on microscope calibration and micrometry.

During the preparation of this book, innumerable friends and colleagues have generously assisted me by providing material and/or advice and I wish to thank, in particular, Dr M. S. Berry, Dr P. F. Brain, Mr R. G. Elias, Mr P. Fleetwood, Mr M. R. Fordy, Mrs M. Griffiths, Dr P. Makings, Dr A. F. Rowley and Mr I. Tew, all of whom are past or present members of the Department of Zoology, University College of Swansea, Mrs P. A. Green of Philip Harris Biological Ltd, and Dr J. G. Richards of HoffmanLa Roche \& Co. Ltd. I am also indebted to Miss B. Jones, Mrs M. Thomas, Miss L. Millett and Mrs P. Llewellyn for typing the manuscript.

Finally, Paul Llewellyn and myself wish to dedicate this book to our respective wives, Carolyn and Pauline, for their magnificent support during the years involved in its preparation.

Swansea, 1981

N.A.R. 